\title{
Diet composition and feeding strategy of John Dory, Zeus faber, in the coastal waters of Korea
}

\author{
Han Ju Kim ${ }^{1}$ Hyeong-Gi Kim² and Chul-Woong $\mathrm{Oh}^{1 *}$
}

\begin{abstract}
Background: Most fish undergo prey switch from juvenile to adult. It is thought that slightly different feeding habits occur among adult fishes due to growth, spawning, habitat change, and so on. Therefore, the diet of the John Dory Zeus faber ( $\geq 24 \mathrm{~cm} \mathrm{TL}$ ) was studied in the coastal waters of Korea by analysis of stomach contents, with comparison by season and size class of diet composition and prey diversity. Monthly samples were taken from February 2017 to January 2018.

Results: The results showed that the John Dory was a piscivorous predator, and pisces had occupied $82.3 \%$ of IRI\%. Trichiurus lepturus and Trachurus japonicus were important preys in all size classes and seasons. Diet composition differed among the size classes and seasons (Chi-square test, $P<0.05$ ). As body size of $Z$. faber increased, the occurrence of benthic fish (Glyptocephalus stelleri) tended to increase. The seasonal prey composition also changed depending on the abundant species of each season.

Conclusions: $Z$. faber is a piscivorous predator. The consumption habits of $Z$. faber appear to different results by their size and seasons. This study suggests that $Z$. faber could be considered an opportunistic predator.
\end{abstract}

Keywords: John Dory, Zeus faber, Diet composition, Feeding habits, Feeding ecology

\section{Background}

John Dory (Zeus faber Linnaeus, 1758) is widely distributed in the Atlantic, Pacific, and Indian oceans, as well as along the entire West African coast (Janssen 1979; Akyol 2001; Yoneda et al. 2002). In Korea, they are distributed on the South Sea and East Sea of Korea (Choi et al. 2011). This species is a demersal fish, inhabiting depths of 50-140 m (Vrgoč et al. 2006; Kim et al. 2013). In Korea, the commercial value of $Z$. faber has recently increased but is treated as bycatch. It is thought that research on their basic ecology is necessary.

Previous studies on feeding habits of $Z$. faber were conducted in eastern Mediterranean Sea (Stergiou and Fourtouni 1991), Portuguese coast (Silva 1999), North

\footnotetext{
*Correspondence: ohcw@pknu.ac.kr

'Department of Marine Biology, Pukyong National University, Busan, South Korea

Full list of author information is available at the end of the article
}

Aegean Sea (Ismen et al. 2013), and South Sea in Korea (Choi et al. 2011; An et al. 2012). All results of them shown that $Z$. faber is a piscivorous predator. However, these studies lack the ecological study on feeding habits because there is only descriptive information about the prey composition of $Z$. faber. To understand the overall dynamics of community feeding ecology, it is necessary to investigate higher predators within marine trophic food webs.

Most fish undergo prey switch. Diet shifts in fish can be influenced by season, environmental factors, interspecific composition, ontogeny, and body size (Gerking 1994; Preciado et al. 2006; Cusa et al. 2019). The prey composition of $Z$. faber also vary with ontogeny. Stergiou and Fourtouni (1991) suggested that changes in feeding can occur based on $14 \mathrm{~cm}$ TL. When $>14 \mathrm{~cm}$ TL, Z. faber consumes benthic and demersal fish exclusively (Stergiou and Fourtouni 1991). On the other hand,

(c) The Author(s). 2020 Open Access This article is licensed under a Creative Commons Attribution 4.0 International License, which permits use, sharing, adaptation, distribution and reproduction in any medium or format, as long as you give appropriate credit to the original author(s) and the source, provide a link to the Creative Commons licence, and indicate if changes were made. The images or other third party material in this article are included in the article's Creative Commons licence, unless indicated otherwise in a credit line to the material. If material is not included in the article's Creative Commons licence and your intended use is not permitted by statutory regulation or exceeds the permitted use, you will need to obtain permission directly from the copyright holder. To view a copy of this licence, visit http://creativecommons.org/licenses/by/4.0/. 
diets of $Z$. faber from along the Portuguese coastline do not show distinct changes (Silva 1999). These studies focused on the dietary changes from juvenile to adult. However, this study thought that the diet of adult $Z$. faber varies with body size, season, and feeding strategy. The objectives of this study were to reveal the overall diet composition and feeding strategy for specimens of $\geq$ $24 \mathrm{~cm}$ TL in the coastal waters of Korea.

\section{Materials and methods}

\section{Sample collection}

A total of 711 samples were monthly collected between February 2017 and January 2018 by commercial bottom trawl net in the coastal waters of Korea $\left(35^{\circ} 58^{\prime} \mathrm{N}\right.$ $129^{\circ} 50^{\prime} \mathrm{E}$ ). Bottom trawl mesh size was $54 \mathrm{~mm}$, and net length was about $40.8 \mathrm{~m}$. The samplings were conducted around $2 \mathrm{~h}$ at a time. All samples were brought in thermos cool boxes to the laboratory. Fish specimens were collected in the range from 24 to $47 \mathrm{~cm}$ (mean \pm SD: $34.10 \pm 4.21$ ) in total length (TL) and from 221.01 to $2458.35 \mathrm{~g}$ (mean \pm SD: $679.42 \pm 278.17$ ) in total weight (TW) (Table 1).

\section{Analysis of stomach contents}

Stomachs of 711 individuals were dissected, and prey items in the stomachs were classified to the lowest taxonomic level by the naked eye and under microscope. Biomass and length of all prey items were measured with an electronic balance to the nearest $0.01 \mathrm{~g}$ and the nearest millimeter. A regression analysis was performed using excel to observe the changes in lengths of prey items according to the sizes of $Z$. faber.

Feeding habits were determined by using the index (Hyslop 1980): (1) the frequency of occurrence $(\% F),(2)$ the numerical percentage $(\% N)$, (3) the weight percentage $(\% W)$, and $(4)$ the index of relative importance (IRI). Indices were calculated for each stomach as follows:

$$
\begin{aligned}
& \% F=\frac{A_{i}}{N} \times 100 \\
& \% N=\frac{N_{i}}{N_{\text {total }}} \times 100 \\
& \% W=\frac{W_{i}}{W_{\text {total }}} \times 100 \\
& \text { IRI }=(\% N+\% W) \times \% F
\end{aligned}
$$

$A_{i}$ is the number of fish with prey $i$ (th) in their stomach, $N$ is the total number of fish with stomach contents, $N_{i}$ is the number of prey $i$ (th), $N_{\text {total }}$ is the total number of prey items $W_{i}$ is the mass of prey $i$ (th), and $W_{\text {total }}$ is the total mass of prey items. IRI was converted into a percentage and expressed as \%IRI.

\section{Data analysis}

To investigate variation of diet according to size group, $Z$. faber was divided into four size classes: $24-30 \mathrm{~cm}(n$ $=143), 31-35 \mathrm{~cm}(n=168), 36-40 \mathrm{~cm}(n=210)$, and $41-47 \mathrm{~cm}(n=190)$. These size groups were divided into four classes based on size at sexual maturity, age, and growth. The first class $(24-30 \mathrm{~cm} \mathrm{TL})$ was sub-adult before maturity (size at first maturity $=30 \mathrm{~cm})(\operatorname{Kim} 2019)$. The other classes were divided according to size at age by Yoneda et al. (2002): $31-35 \mathrm{~cm}$ at $6-8$ years, $35-40$ $\mathrm{cm}$ at $8-10$ years, and $41-47 \mathrm{~cm}$ at $10-14$ years.

Seasonal variation of diet was investigated for four seasons: spring (March-May, $n=150$ ), summer (JuneAugust, $n=161$ ), autumn (September-November, $n=$ 210 ), and winter (December-February, $n=190$ ). Statistical differences in diet composition among size classes and seasons were employed by a chi-square test of the frequencies of a given prey categories (Sokal and Rohlf 1995).

Table 1 Monthly number of samples and range of total length (TL) for Zeus faber in the coastal waters of Korea

\begin{tabular}{llllll}
\hline Month & Number of samples & Range of TL $(\mathrm{cm})$ & Mean TL \pm SD $(\mathrm{cm})$ & Range of TW $(\mathrm{cm})$ & Mean TW \pm SD $(\mathrm{cm})$ \\
\hline Feb. & 50 & $24.7-47.7$ & $35.6 \pm 5.4$ & $562.82-1430.02$ & $846.19 \pm 194.48$ \\
Mar. & 50 & $25.3-42.1$ & $35.7 \pm 3.0$ & $182.23-2438.35$ & $818.87 \pm 465.68$ \\
Apr. & 50 & $25.4-44.5$ & $34.7 \pm 5.1$ & $418.02-1093.88$ & $722.23 \pm 164.36$ \\
May & 50 & $25.4-47.6$ & $35.3 \pm 4.4$ & $292.78-1548.35$ & $706.06 \pm 296.52$ \\
Jun. & 50 & $26.6-44.3$ & $32.1 \pm 4.4$ & $355.87-1460.91$ & $733.52 \pm 334.84$ \\
Jul. & 51 & $25.2-42.0$ & $32.4 \pm 4.9$ & $295.48-1460.91$ & $539.63 \pm 249.08$ \\
Aug. & 60 & $24.7-47.4$ & $32.9 \pm 4.3$ & $259.74-1381.22$ & $585.17 \pm 304.20$ \\
Sep. & 70 & $26.6-44.8$ & $32.4 \pm 4.1$ & $247.24-1739.52$ & $616.6 \pm 259.14$ \\
Oct. & 70 & $28.2-41.3$ & $33.1 \pm 2.7$ & $314.39-1367.95$ & $585.70 \pm 226.11$ \\
Nov. & 70 & $25.8-43.4$ & $33.4 \pm 3.3$ & $384.78-1219.33$ & $611.25 \pm 167.91$ \\
Dec. & 70 & $26.0-40.6$ & $34.3 \pm 3.4$ & $354.71-1584.81$ & $658.41 \pm 230.80$ \\
Jan. & 70 & $33.5-43.4$ & $37.1 \pm 2.3$ & $356.53-1208.96$ & $730.01 \pm 205.37$ \\
\hline
\end{tabular}


Niche breadth analysis was conducted using the Shannon-Wiener diversity index $\left(H^{\prime}\right)$ (Colwell and Futuyma 1971),

$$
H^{\prime}=-\sum_{i=1}^{S} P_{i} \ln P_{i}
$$

where $P_{i}$ is the proportion of individuals belonging to $i$ th species. $s$ is the total number of different prey categories consumed by predator. The value of $H^{\prime}$ increases with species diversity.

\section{Results}

\section{Diet compositions}

Of the 711 stomachs examined, a total of 24 prey species were found. Percentage of empty was $47.3 \%$. Prey items were divided into three categories: pisces, crustacean, and Cephalopoda. The index of relative importance (IRI) analysis recovered pisces as the most important prey category (82.3\%), followed by crustaceans (17.5\%) and Cephalopoda (0.3\%) (Table 2). Z. faber were shown to be piscivorous that consume fishes as principal prey items.

\section{Difference of diet by size class}

For each of the four size classes, Trichiurus japonicus and Trachurus japonicus were the most common prey by biomass (Fig. 1). Engraulis japonicus was an important prey in the $24-30 \mathrm{~cm}$ and $31-35 \mathrm{~cm}$ size classes, but the occurrence of E. japonicus from the $36-40 \mathrm{~cm}$ group was greatly reduced. In the large fish $(>38 \mathrm{~cm})$, the proportion of Glyptocephalus stelleri increased markedly. There is no significant difference in the size of the prey items (Trichiurus japonicus, E. japonicus, Trachurus japonicus, and G. stelleri) according to the TL $(P>0.05)$. There was a significant difference in the proportions of prey categories consumed by the four size classes $\left(x^{2}=\right.$ 318.24, $d f=24, P<0.001)$.

\section{Difference of diet by season class}

In all seasons, Trichiurus japonicus and Trachurus japonicus were consumed (Fig. 2). Trichiurus japonicus was the most common prey item by \%IRI in spring (34.9\%) and summer (31.3\%). Overall crustacean prey biomass increased during summer and autumn. In autumn, E. japonicus dominated the prey mass, making up $37.4 \%$ of the total diet, respectively. \%IRI of Trachurus japonicus and G. stelleri increased in winter to $16.8 \%$ and $11.9 \%$, respectively. We found a significant difference in diet compositions among seasons $\left(x^{2}=499.41, d f=24, P<0.001\right)$.

\section{Difference of diet by size and season}

There were variation of diet in size group by season, as shown in the percentage of IRI (Fig. 3). Dominant preys of 24-30 cm group consisted of pelagic fishes in all the seasons; Trichiurus japonicus in spring (93.5\%) and summer
Table 2 Diet composition in the stomach contents

\begin{tabular}{|c|c|c|c|c|}
\hline Prey items & $\% F$ & $\% \mathbf{N}$ & $\% W$ & $\% \mid \mathrm{RI}$ \\
\hline Pisces & & & & 82.3 \\
\hline Acropoma japonicum & 4.0 & 1.7 & 3.6 & 1.0 \\
\hline Argentina kagoshimae & 1.0 & 0.3 & 0.3 & 0.0 \\
\hline Coelorinchus multispinulosus & 0.5 & 0.2 & 0.3 & 0.0 \\
\hline Chelidoperca hirundinacea & 0.5 & 0.2 & 0.5 & 0.0 \\
\hline Cleisthenes pinetorum & 1.0 & 0.3 & 2.9 & 0.2 \\
\hline Cololabis saira & 1.0 & 2.8 & 1.7 & 0.2 \\
\hline Decapterus muroadsi & 0.5 & 0.3 & 0.9 & 0.0 \\
\hline Doederleinia berycoides & 2.0 & 0.6 & 1.6 & 0.2 \\
\hline Engraulis japonicus & 10.9 & 7.6 & 6.0 & 7.2 \\
\hline Glyptocephalus stelleri & 5.0 & 3.0 & 14.5 & 4.2 \\
\hline Larimichthys polyactis & 2.5 & 0.9 & 4.7 & 0.7 \\
\hline Lepidotrigla guentheri & 0.5 & 0.2 & 0.2 & 0.0 \\
\hline Malakichthys wakiyae & 1.0 & 0.3 & 0.2 & 0.0 \\
\hline Pagrus major & 1.0 & 0.5 & 1.0 & 0.1 \\
\hline Pennahia argentata & 1.5 & 0.5 & 2.5 & 0.2 \\
\hline Psenopsis anomala & 1.5 & 0.5 & 3.5 & 0.3 \\
\hline Scomber japonicus & 0.5 & 0.2 & 1.6 & 0.0 \\
\hline Trachurus japonicus & 8.5 & 2.8 & 10.4 & 5.4 \\
\hline Trichiurus japonicus & 18.9 & 7.3 & 23.9 & 28.6 \\
\hline Unidentified fish & 28.4 & 9.5 & 15.0 & 33.8 \\
\hline Crustacean & & & & 17.5 \\
\hline Plesionika izumiae & 0.5 & 2.0 & 0.1 & 0.1 \\
\hline Pandalus eous & 6.0 & 57.5 & 2.4 & 17.4 \\
\hline Unidentified shrimp & 0.5 & 0.2 & 0.0 & 0.0 \\
\hline Cephalopoda & & & & 0.3 \\
\hline Todarodes pacificus & 2.0 & 0.6 & 2.2 & 0.3 \\
\hline Sepiola birostrata & 0.5 & 0.2 & 0.0 & 0.0 \\
\hline
\end{tabular}

$\% F$ frequency of occurrence, $\% N$ numerical percentage, $\% W$ percentage weight, $\% I R I$ percentage index of relative importance

(29.3\%), E. japonicus (63.4\%) in autumn, and Trachurus japonicus (50.0\%) in winter (Fig. 3). In $31-35 \mathrm{~cm}$ group, Trichiurus japonicus (35.5\%) was consumed as dominant preys in spring, and crustacean was mainly prey items in summer (45.9\%) and autumn (59.8\%). In winter, Acropoma japonicum and Trachurus japonicus were dominant, making up $46.0 \%$ and $31.5 \%$, respectively. In $36-40 \mathrm{~cm}$ group, Trichiurus japonicus was the most important prey item in all the seasons. In $41-47 \mathrm{~cm}$ group, G. stelleri was consumed as a main prey item in all the seasons expect autumn in which Psenopsis anomala (58.4\%) and Larimichthys crocea (29.4\%) were consumed.

\section{Trophic diversity}

Trophic diversity of $Z$. faber was generally low. Among the size classes, trophic diversity was highest in the 31- 


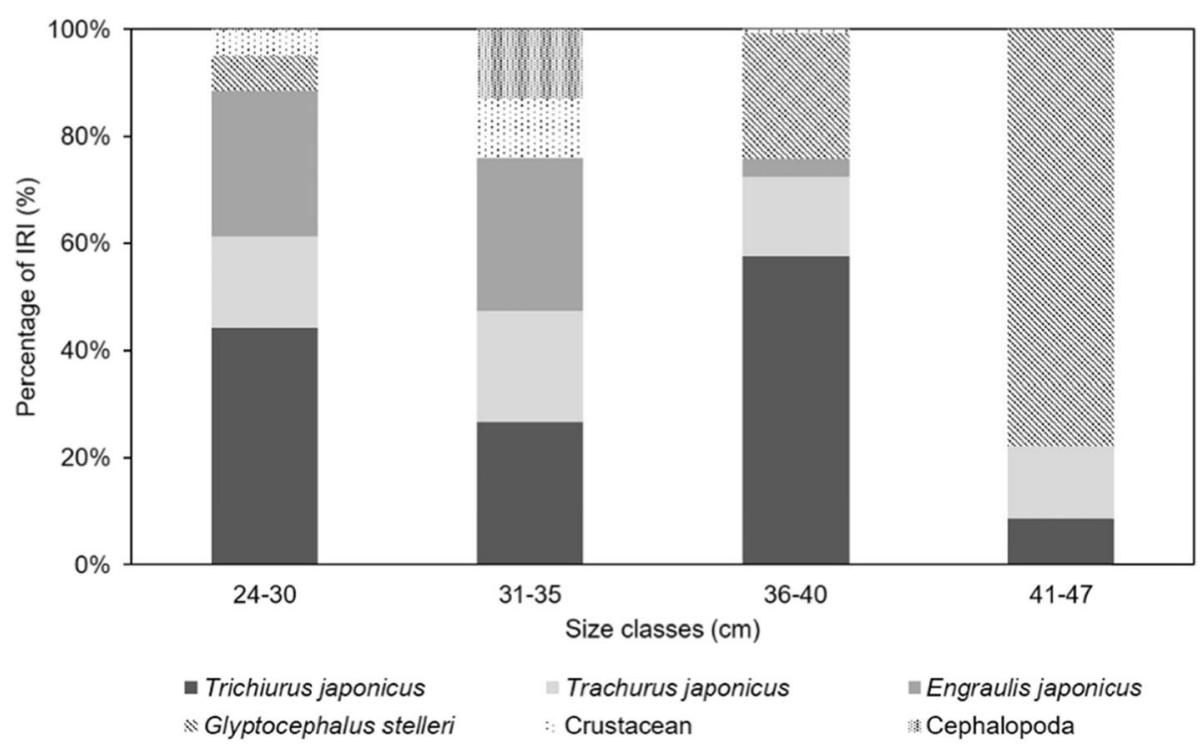

Fig. 1 Variation of the diet composition by the percentage IRI by size classes

$35 \mathrm{~cm}$ group and lowest in the $24-30 \mathrm{~cm}$ group (Fig. 4a). This confirmed that as body size increased, dietary variability also increased. In terms of season, autumn and summer obtained the highest trophic diversity (Fig. 4b), indicating that more prey items were consumed during this time period than in other seasons.

\section{Discussion}

The diet of $Z$. faber consisted of a limited range of prey items from cephalopods to pisces. It was a total of 24 prey species. Despite the fact that $Z$. faber fed on a range of prey items, fish dominated the diet in all seasons. In particular, Trichiurus japonicus, Trachurus japonicus, and E. japonicus were consumed in all seasons, which was similar to all the previous studies performed in Korea (Huh et al. 2006; Choi et al. 2011; An et al. 2012). $Z$. faber has narrow dietary niche width (15-24 prey items) in all previous studies (Huh et al. 2006; Choi et al. 2011; An et al. 2012), which is one of the characteristics of piscivorous fish. This feeding behavior could be attributed to a large mouth, suction capabilities, and extensive swimming maneuverability (Stergiou and Fourtouni 1991; An et al. 2012).

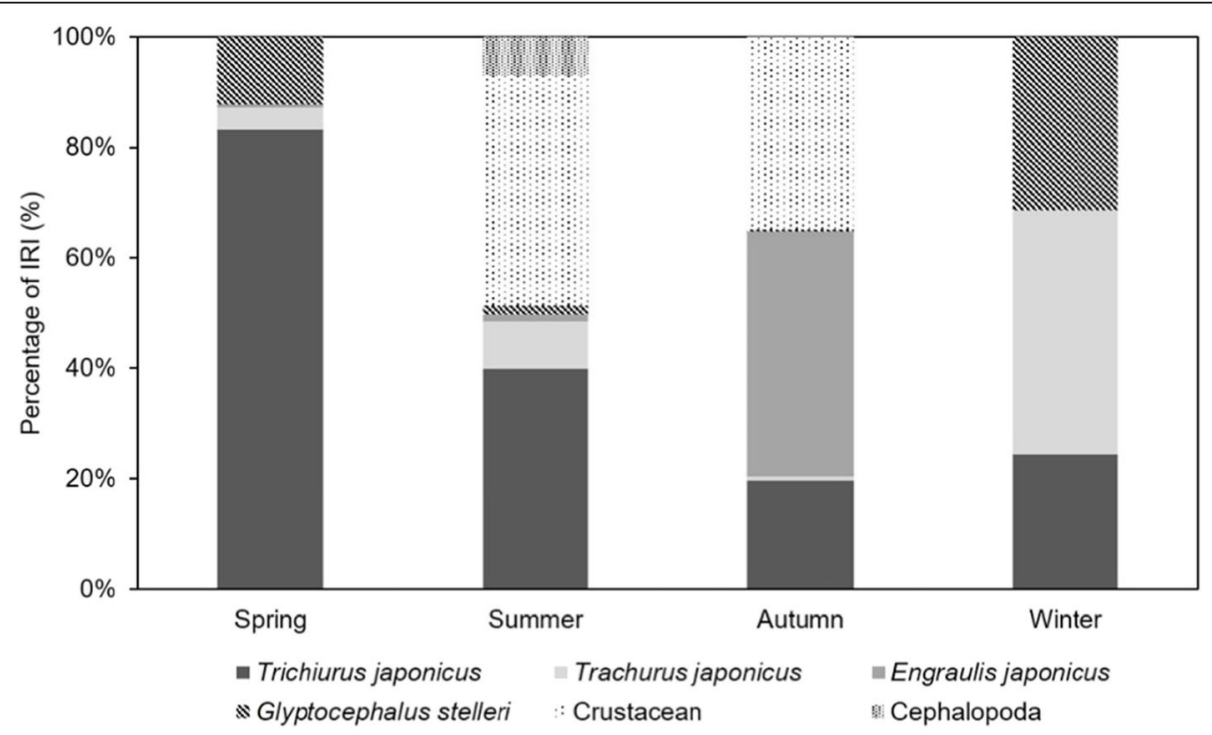

Fig. 2 Seasonal variation in the diet composition by the percentage of IRI 
(a) $24-30 \mathrm{~cm}$

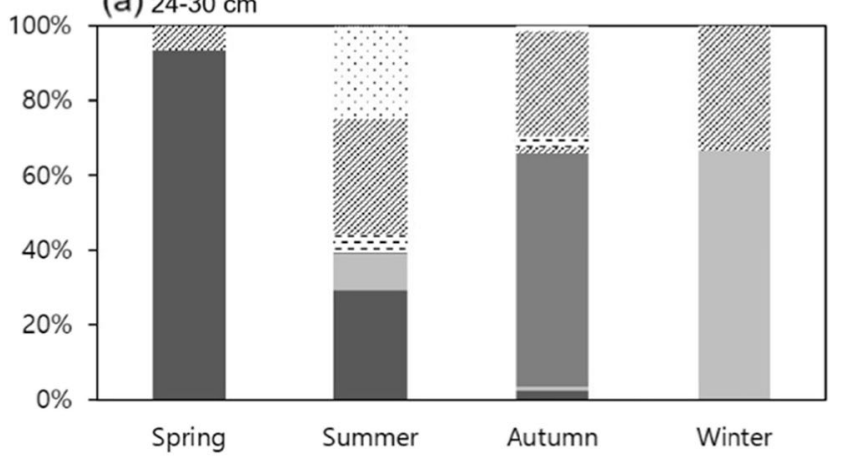

(b) $31-35 \mathrm{~cm}$

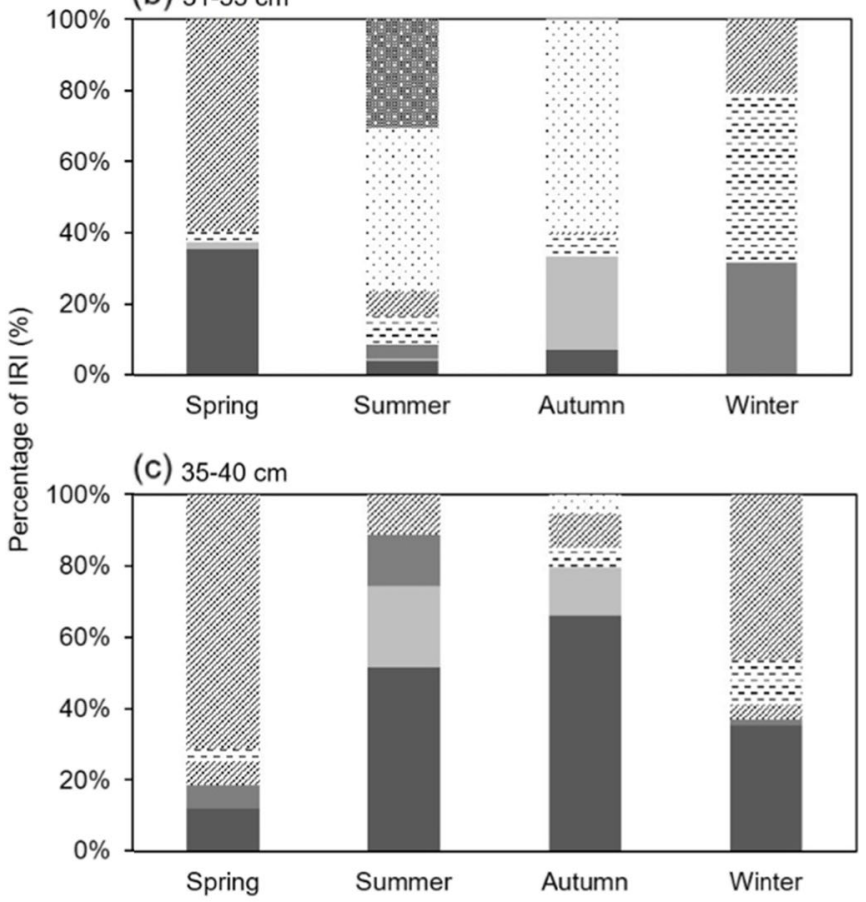

(d) $41-47 \mathrm{~cm}$

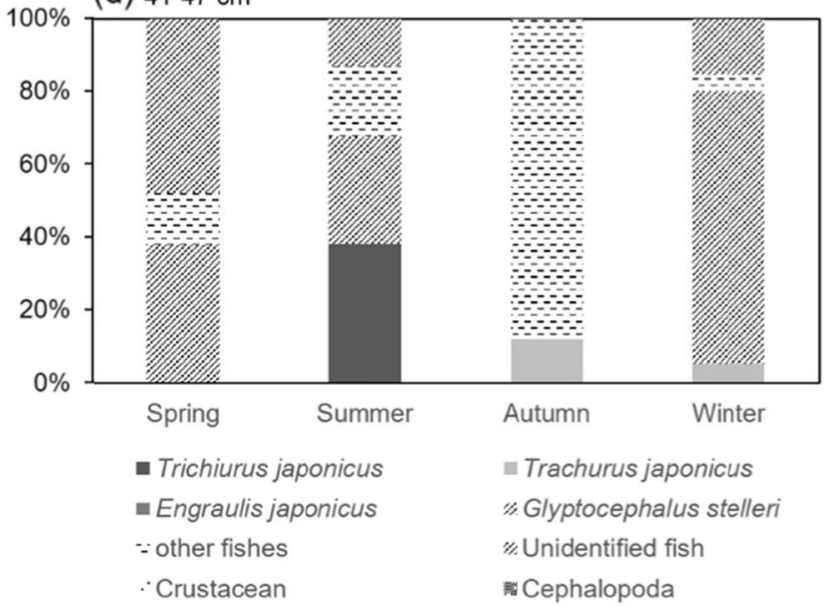

Fig. 3 Variation of diet composition between size classes and seasons by the percentage of IRI 

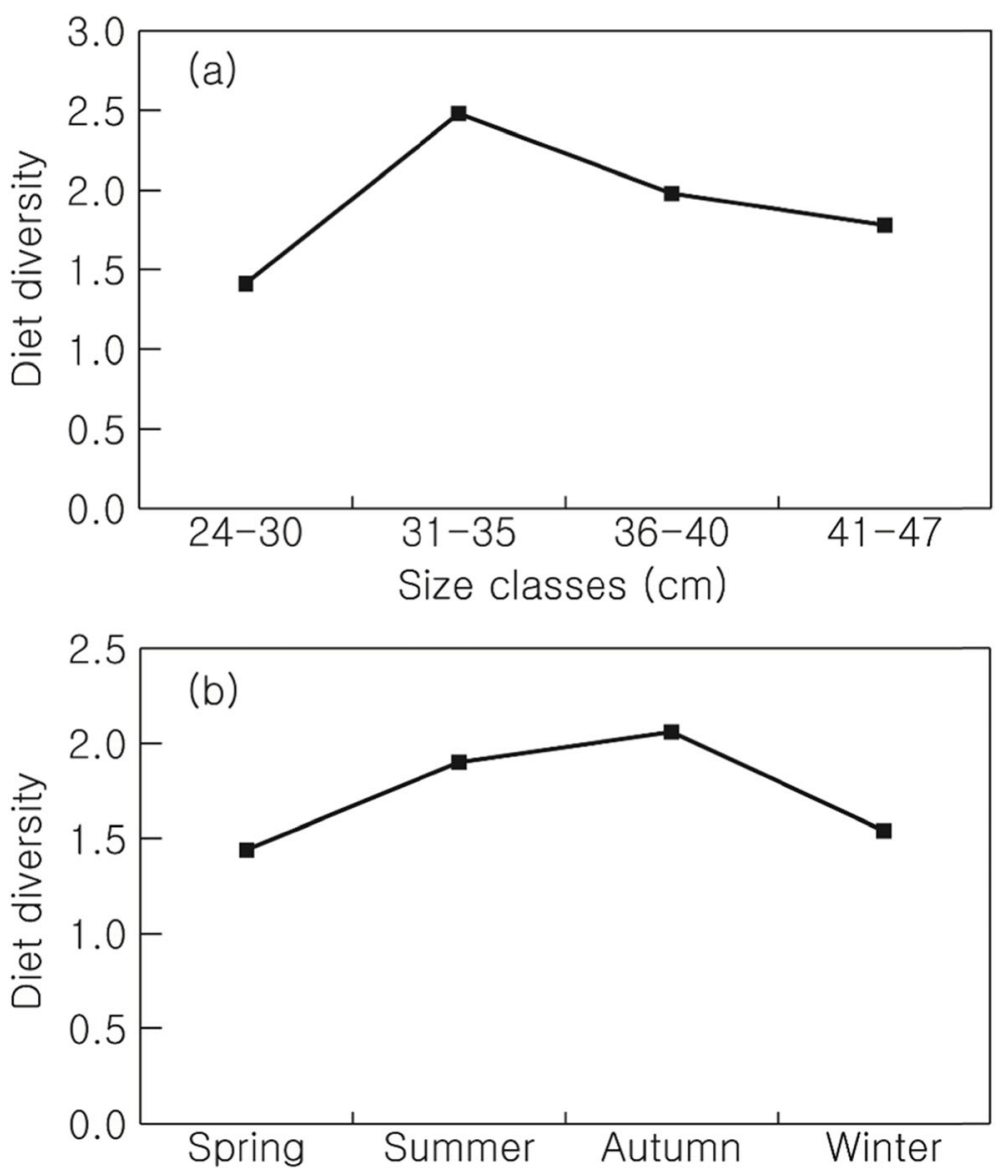

Fig. 4 Trophic diversity of prey items; a size classes and $\mathbf{b}$ seasons

In the Gori study, however, the main preys included Psenopsis anomala, Conger myriaster, and Glossando semifasciata (Huh et al. 2006). In Geomun-island, dominant preys consisted of Scomber japonicus and Callanthias japonicus (An et al. 2012). These results indicated that the prey items varied with habitats. $Z$. faber are opportunistic species which consume mainly abundant and diverse species according to habitat. Similar results are observed in other fishes, Lophius litulon (Choi et al. 2011; Park et al. 2014), Coryphaena hippurus (Jeong et al. 2017), and Muraenesox cinereus (An et al. 2011).

In the present study, Trichiurus japonicus was the most commonly consumed species, as reported previously (Huh et al. 2006; Choi et al. 2011; An et al. 2012). T. japonicus inhabits at depths of 40 to $120 \mathrm{~m}$ (Martins and Haimovici 1997), which overlaps the habitat of Z. faber (50 to $140 \mathrm{~m}$ ) (Vrgoč et al. 2006; Kim et al. 2013). Fishes with a long body swim in a head-up state with limited swimming capabilities (Wilson 1958). In addition, the body of T. japonicus is thin, long, and reflective. Therefore, $Z$. faber can efficiently detect $T$. japonicus at any depth (Stergiou and Fourtouni 1991). In the eastern
Mediterranean, long body fishes such as Cepola macrophthalma are most commonly consumed by Z. faber (Stergiou and Fourtouni 1991).

Z. faber consumed Trichiurus japonicus and E. japonicus, which is schooling fish. $Z$. faber has a stalking ability to consume prey fish selected in a school or group (Ressell 1983). Two species inhabit the wild layer of the ocean, indicating that $Z$. faber moves to the surface layer to feed. Previous studies have found Jack Mackerel (Trachurus symmetricus) in the eastern Mediterranean and along the Portuguese coastline (Stergiou and Fourtouni 1991; Silva 1999). Trichiurus japonicus and E. japonicus were the most abundant species in the coastal waters of Korea (Cha 2010), which indicates that Z. faber is an opportunistic feeder by energy effectivity.

In the present study, predation by Z. faber was not significantly dependent on prey size. As there are no distinct morphological changes related to feeding ability with growth (Stergiou and Fourtouni 1991), large specimens of $Z$. faber expand their prey options by altering feeding behavior. In this study, individuals less than 30 $\mathrm{cm}$ preferred surface fish as E. japonicus and Trachurus japonicus, while specimens of $Z$. faber up to $38 \mathrm{~cm}$ were 
found to feed on the benthic species G. stelleri. In other words, as body size increased, Z. faber preferred fish lived deep water such as Conger myriaster (Huh et al. 2006) and Micromesistius poutassou (Silva 1999). This indicates that $Z$. faber can exploit the entire water column when feeding. This partial dietary change can reduce intraspecific competition by resource partitioning (Gerking 1994). After consuming a diet of small fish and zooplankton during the juvenile stage, adult $Z$. faber (> $24 \mathrm{~cm}$ ) undergo a transformation in prey selection to reduce intraspecific competition.

$Z$. faber consumed more prey items during summer and autumn than in other seasons. Some fishes that inhabited Korea tend to spend the winter in near Jeju Island and East China Sea. In the spring, as temperature rise, they come back to the coastal waters of Korea due to spawning ground (Noh et al. 2013). Therefore, species abundance in summer becomes higher, compared with winter. We found that crustaceans were the dominant species in summer and autumn in this study because of the behavior and life history of crustacean prey (Xue et al. 2005; Blasina et al. 2010). P. eous used as prey mainly migrate to inshore $(<50 \mathrm{~m})$ for the larval hatch during late winter and early spring (Park et al. 2012; Richards 2012). The density of crustaceans increases as the hatched crustaceans recruit in summer. Also, $P$. eous can be captured more than other invertebrates because $P$. eous inhabit in various water depths up to $600 \mathrm{~m}$ deep (Park et al. 2012). Therefore, larger individuals of $Z$. faber inhabit in deeper depths and can consume crustaceans abundantly. Stergiou and Fourtouni (1991) found that only individuals up to $14 \mathrm{~cm}$ consumed tiny crustaceans, but this study obtained different results, as crustaceans were consumed by specimens of $Z$. faber up to $38 \mathrm{~cm}$, and up to 168 crustaceans were consumed at a time. Along the Portuguese coastline, crustaceans are also an important food source for specimens up to $25 \mathrm{~cm}$ (Silva 1999). The short period of research in the Mediterranean has showed different results to this study and a previous study of $Z$. faber.

\section{Conclusion}

The present study was performed by commercial trawl and collected adult $Z$. faber ( $>24 \mathrm{~cm}$, TL). A total of 24 prey items were found and tropic diversity was low because Z. faber consumes mainly fishes. As Z. faber grew, they consumed the demersal fish species that live near their habitat. We found that prey items of $Z$. faber also changed depending on the abundant species of each season. As this results, Z. faber could be considered a piscivorous fish and opportunistic predator which consume mainly fish prey items from various depth of waters.
Abbreviation

SD: Standard deviation

\section{Acknowledgements}

This work was supported by a Research Grant of Pukyong National University (2019).

\section{Authors' contributions}

HanJu Kim carried out the field study and performed the analysis, and wrote the manuscript. Hyeong-Gi Kim participated in the design of the study, conducted field study, and reviewed the manuscript. Chul-Woong Oh conceived the study and reviewed/edited the manuscript. HanJu Kim and Chul-Woong Oh made equal contributions to this study. All authors read and approved the final manuscript.

\section{Funding}

Not applicable

\section{Availability of data and materials}

The datasets generated during and/or analyzed during the current study are available from the corresponding author on reasonable request.

Ethics approval and consent to participate

Not applicable

Consent for publication

Not applicable

Competing interests

The authors declare that they have no competing interests.

\section{Author details}

${ }^{1}$ Department of Marine Biology, Pukyong National University, Busan, South Korea. ${ }^{2}$ School of Earth and Environmental Sciences and Research Institute of Oceanography, Seoul National University, Seoul 08826, South Korea.

Received: 25 November 2019 Accepted: 17 March 2020

Published online: 31 March 2020

\section{References}

Akyol O. Some biological properties and stock estimates of Zeus faber L., 1758 (Pisces, Zeidae) in the Aegean coasts of Turkey. Ege J FAS. 2001;18:39-46.

An YS, Park JM, Ye SJ, Jeong JM, Baeck GW. Feeding habits of John dory, Zeus faber in the coastal waters of Geomun-Do, Korea. Korean J Ichthyol. 2012;24: 20-6.

Blasina GE, Barbini SA, de Astarloa D. JM. Trophic ecology of the black drum, Pogonias cromis (Sciaenidae), in Mar Chiquita Coastal Lagoon (Argentina). J Appl Ichthyol. 2010;26:528-34.

Cha BY. Species composition and abundance of fish in the water off Geomun Island of the southern sea, Korea. Korean J Fish Aquat Sci. 2010;22:168-78.

Choi JH, Sung BJ, Lee DW, Kim JB, Oh TY, Kim JN. Feeding habits of yellow goose fish Lophius litulon and John Dory Zeus faber in the South Sea of Korea. Korean J Fish Aquat Sci. 2011;4:435-41.

Colwell RK, Futuyma DJ. On the measurement of niche breadth and overlap. Ecology. 1971;52:567-76.

Cusa M, Jørgen Berge J, Varpe $\varnothing$. Seasonal shifts in feeding patterns: individual and population realized specialization in a high Arctic fish. Ecol Evol. 2019; 180:631-44.

Gerking SD. Feeding ecology of fish. San Diego:Academic Press Inc. 1994.

Huh SH, Park JM, Beack GW. Feeding habits of John dory Zeus faber in the Coastal Waters off Gori, Korea. Korean J Fish Aquat Sci. 2006;39:357-62.

Hyslop EJ. Stomach contents analysis - a review of methods and their application. J Fish Biol. 1980;17:411-29.

Ismen A, Arslan M, Yigin CC, Bozbay N. Age, growth, reproduction and feeding of John Dory, Zeus faber (Pisces: Zeidae), in the Saros Bay (North Aegean Sea). J Appl Ichthyol. 2013;29(1):125-31.

Janssen GM. The occurrence of Zeus faber (Linnaeus, 1758) in the coastal waters of the Netherlands (Pisces, Zeiformes). Bull Zool Mus. 1979;6:153-5.

Jeong JM, Choi J, Im Y-J, Kim JN. Feeding habits of dolphinfish Coryphaena hippurus in the South Sea of Korea. Korean J Fish Aquat Sci. 2017:541-6. 
Kim HJ. Population ecology of John dory, Zeus faber, in the coastal waters of Korea. Busan: Pukyoung national university; 2019.

Kim HR, Choi JH, Park WG. Vertical distribution and feeding ecology of the black scraper, Thamnaconus modestus, in the Southern Sea of Korea. Turk J Fish Aquat Sc. 2013;13:249-59.

Martins AS, Haimovici M. Distribution, abundance and biological interactions of the cutlassfish Trichiurus lepturus in the southern Brazil subtropical convergence ecosystem. Fish Res. 1997;30:217-27.

Noh HS, Kwon S, Jo SI, Im SC, Lee Cl. Seasonal composition and seasonal variation of fish at Hallyeohaesnang Sangju.Gumsan region and Geoje.Haegumkang Region, in the southern sea of Korea. J Nati Park Res. 2013;4:137-49.

Park HM, Oh CW, Sohn MH. Distribution and reproductive aspects of the pandalid shrimp, Pandalus eous, in the deep sea of the east sea, Korea. Anim Cells Syst. 2012:16:77-84.

Park JM, Huh S-H, Jeong JM, Baeck GW. Diet composition and feeding strategy of yellow goosefish, Lophius litulon (Jordan, 1902), on the southeastern coast of Korea. J Appl Ichthyol. 2014;30:151-5.

Preciado I, Velasco F, Olaso I, Landa J. Feeding ecology of black anglerfish Lophius budegassa: seasonal, bathymetric and ontogenetic shifts. J Mar Biol Assoc UK. 2006;86:877-84.

Ressell BC. The food and feeding habits of rocky reef fish of north-eastern New Zealand. New Zeal J Mar Fresh. 1983;17:121-45.

Richards RA. Phenological shifts in hatch timing of northern shrimp Pandalus borealis. Mar Ecol Prog Ser. 2012;456:149-58.

Silva A. Feeding habits of John dory, Zeus faber, off the Portuquese continental coast. J Mar Biol Assoc. 1999;79:333-40.

Sokal RR, Rohlf FJ. Biometry. New York: WH Freeman \& Col; 1995.

Stergiou Kl, Fourtouni H. Food habits, ontogenetic diet shift and selectivity in Zeus faber Linnaeus, 1758. J Fish Biol. 1991;39:589-603.

Vrgoč N, KrstulovićŠifner S, Dadić V, Jukić-Peladić S. Demographic structure and distribution of John dory, Zeus faber L. 1758, in the Adriatic Sea. J Appl Ichthyol. 2006;22:205-8.

Wilson DP. Notes from the Plymouth Aquarium. III. J Mar Biol Asso. 1958;37:299307.

Xue Y, Jin X, Zhang B, \& Liang Z. Seasonal, diel and ontogenetic variation in feeding patterns of small yellow croaker in the central Yellow Sea. J Fish Biol. 2005; $7: 33-50$

Yoneda M, Yamasaki S, Yamamoto K, Horikawa H, Matsuyama M. Age and growth of John Dory, Zeus faber (Linnaeus, 1758), in the East China Sea. ICES J Mar Sci. 2002:749-56.

\section{Publisher's Note}

Springer Nature remains neutral with regard to jurisdictional claims in published maps and institutional affiliations.

Ready to submit your research? Choose BMC and benefit from:

- fast, convenient online submission

- thorough peer review by experienced researchers in your field

- rapid publication on acceptance

- support for research data, including large and complex data types

- gold Open Access which fosters wider collaboration and increased citations

- maximum visibility for your research: over $100 \mathrm{M}$ website views per year

At $\mathrm{BMC}$, research is always in progress.

Learn more biomedcentral.com/submissions 